\title{
SURFACE SOIL THICKNESS AND COTTON DEVELOPMENT
}

\author{
By Dr. A. SReEnivasan \\ Institute of Plant Industry, IndoRe
}

T $\mathrm{N}$ profile studies with the black cotton soil in Malwa, it has been observed that the thickness of the productive surface layer differed appreciably even between adjoining rich and poor fields. Often, the nature of the surface soil also varied, particularly in regard to openness, permeability and crumb structure. It therefore appeared probable that the
There were five randomized blocks in each of the two fields with eight plots per block. Experimental plot size was $6 \mathrm{ft}$. $\times 6 \mathrm{ft}$. containing six rows of plants one foot apart, thus leaving a non-experimental margin of one row on each side and one foot at each end of the plot. There were 3 -ft. paths between and all round the plots which were edged with bricks.

TABLE I.

\begin{tabular}{|c|c|c|c|c|c|c|c|}
\hline & \multirow{3}{*}{$\begin{array}{l}\text { Control- } \\
\text { untreated } \\
\text { (1) }\end{array}$} & \multicolumn{6}{|c|}{ Thickness in inches of surface soil added from } \\
\hline & & \multicolumn{4}{|c|}{ Same field } & \multicolumn{2}{|c|}{ Rich fleld } \\
\hline & & $\begin{array}{c}\text { Two } \\
\text { (3) }\end{array}$ & $\underset{(4)}{\text { Three }}$ & $\underset{(5)}{\text { Four }}$ & $\begin{array}{c}\text { Five } \\
\text { (6) }\end{array}$ & $\begin{array}{c}\text { Two } \\
\text { (7) }\end{array}$ & $\begin{array}{c}\text { Five } \\
(8)\end{array}$ \\
\hline \multicolumn{8}{|l|}{ WELL-DRAINED FIELD (12D) } \\
\hline Yield of seed cotton (in ounces) & $34 \cdot 8$ & $\begin{array}{cr}55 \cdot 3 & 63 \cdot 3 \\
\text { Critical } & \text { Order of merit }\end{array}$ & $\begin{array}{l}58 \cdot 0 \\
\text { ference } \\
(8)(3)(2)\end{array}$ & $\begin{array}{l}57 \cdot 0 \\
0 \cdot 01) \\
(5)(6)(\end{array}$ & $\cdot 68 \cdot 0$ & $44 \cdot 3$ & $77 \cdot 8$ \\
\hline \multicolumn{8}{|l|}{ POORLY DRAINED FIELD (27 S.E.) } \\
\hline Yield of seed cotton (in ounces) & $9 \cdot 5$ & $\begin{array}{cr}16 \cdot 8 & 16 \cdot 0 \\
\text { Order of merit }\end{array}$ & $\begin{array}{l}17 \cdot 0 \\
\text { fference } \\
(6)(5)(8\end{array}$ & $\begin{aligned} & 24 \cdot 5 \\
= & 0 \cdot 01) \\
& (3)(4)\end{aligned}$ & $5^{28 \cdot 3}$ & $15 \cdot 0$ & $24 \cdot 0$ \\
\hline
\end{tabular}

TABLE II

\begin{tabular}{|c|c|c|c|c|c|c|c|c|}
\hline Loose surface soil from: & $\begin{array}{l}\text { Carbon } \\
\text { per cent }\end{array}$ & $\begin{array}{l}\text { Nitrogen } \\
\text { per cent }\end{array}$ & $\begin{array}{c}\text { Available } \\
\mathrm{K}_{2} \mathrm{O} \\
\text { per cent }\end{array}$ & $\begin{array}{c}\text { Available } \\
\mathbf{P}_{2} \mathbf{O}_{5} \\
\text { per cent }\end{array}$ & $\begin{array}{c}\text { Exchange } \\
\text { capacity } \\
\text { m.e. } \\
\text { per cent }\end{array}$ & $\begin{array}{c}\text { Pore space } \\
\text { c.c. } \\
\text { per cent }\end{array}$ & $\begin{array}{l}\text { Structural } \\
\text { coefficient }\end{array}$ & $p \mathrm{H}$ \\
\hline Poorly drained fleld (27 S.E.) & $0 \cdot 407$ & $0 \cdot 064$ & 0.0037 & $0 \cdot 014$ & $38 \cdot 0$ & $51 \cdot 6$ & $0 \cdot 44$ & $8 \cdot 6$ \\
\hline Well-drained fleld $(12 D)$ & 0.436 & 0.076 & 0.0039 & 0.013 & $38 \cdot 8$ & $53 \cdot 9$ & 0.52 & $8 \cdot 4$ \\
\hline Rich field $(42 N)$ & $0 \cdot 604$ & 0.077 & $0 \cdot 0044$ & $0 \cdot 013$ & $40 \cdot 1$ & $55 \cdot 8$ & 0.58 & $8 \cdot 7$ \\
\hline
\end{tabular}

friable loose surface soil in a field was closely associated with its fertility.

The normal drainage water from fields during rains removes with it a certain amount of the finer fractions of the upper soil layers, but beyond this, it is essential to conserve the surface soil from erosion losses. A knowledge of the depth of the surface soil which it is necessary to conserve will be of value in determining the efficiency of erosion control.

During the 1939 kharif season, a small plot $(8 \mathrm{ft}$. $\times$ $8 \mathrm{ft}$.) experiment was carried out to ascertain what depth of the surface soil is optimum for cotton development, and whether it is enough to conserve the existing soil of a field or whether importation of surface soil from a rich field will be of any benefit to a poor field.

The test was carried out on the Institute fields, $12 D$ and $27 S . E$. The former is a field of medium fertility and is well drained, while the latter is a badly drained field with very poor crop growth. The rich surface soil required for the experiment was taken from field $42 N$. Addition of average, loose, hand-gathered surface soil from the same field was made in thicknesses of $1,2,3,4$ and 5 in. respectively. Addition of surface soil from the rich field was made in thicknesses of 2 and 5 in. only.
The seeds (variety Malvi $9-20$ ) were sown by dibbling. The yields of seed cotton for the different treatments are given in Table $\mathrm{I}$.

Addition of loose surface soil from the same field increased the yield of cotton in both the fields, but while in the well-drained field the best result is obtained with the addition of a 2-in. layer of surface soil, the poorly drained field shows in general increasing differences in yield with increased additions of surface soil, a 5-in. layer giving the maximum yield. Lack of proper drainage naturally results in surface wash during periods of heavy rainfall and consequent loss in the fertility of the field ( $c f$. the yield figures for the control plots of the two fields). Besides, the difference between the two fields in their response to treatments also shows the relative richness of their surface soils. This fact is further borne out by the results of laboratory examination of these surface soils (Table II).

Addition of surface soil from the rich field also increased the yield significantly in both the fields, the response being better with the greater thickness. But, considering the cost of importation, this is not likely to be more profitable compared to addition of soil from the same field.

These results bear out the value of the conservation of surface soil that may be achieved by erosion control. 